\title{
Austrian Economics Today
}

\author{
Reinhard Neck
}

Published online: 13 March 2014

(C) International Atlantic Economic Society 2014

The recent financial and economic crisis has raised doubts about mainstream economics which, according to many observers, were not able to predict this event and had considerable difficulties in providing convincing explanations and policy prescriptions to deal with its consequences. This has led to a revival of heterodox alternatives to neoclassical economic theories, including Post-Keynesian, institutionalist, and even Marxist alternatives to the accumulated wisdom of general equilibrium economics. Most of these heterodox approaches lead to policy recommendations more to the "left" of neoclassical ones, implying a more active role of government in regulation and stabilization policies. On the other hand, for a long time public choice theorists have pointed towards the danger of government failure under such "paternalistic" schemes of public policy design. In any case, now the door seems to be open for a re-evaluation of alternative approaches to economics and for recognizing the requirement of dealing with critiques of the neoclassical paradigm.

Austrian Economics, or more precisely the Austrian School of Economics, is unique in providing a theoretical framework which, although distinctly different from Walrasian general equilibrium, rests on methodological individualism and the assumption of rationality of economic agents, two pillars of neoclassical economics, and leads to policy conclusions that are located to the "right" of the mainstream in pleading for unfettered markets, free trade and minimal government. Even if some of the Austrians' propositions are deemed provocative and unrealistic by many economists, it is worthwhile examining this alternative framework which has a long and distinguished career hearkening back to the time of the neoclassical revolution in the 1870s (Menger 1871). A reconsideration of the Austrian contribution may provide insights which help explain economic phenomena of today and enrich the corpus of economic theory in various ways.

The Austrian School of Economics was founded by Carl Menger, continued in the "second generation" by Eugen von Böhm-Bawerk and Friedrich von Wieser, in the "third generation" by Ludwig von Mises, and later by such eminent economists as Oskar Morgenstern and Nobel laureate Friedrich August von Hayek. While all these economists came from the Austrian part of the Habsburg monarchy and later from

R. Neck $(\bowtie)$

Department of Economics, Alpen-Adria-Universität Klagenfurt, Klagenfurt, Austria

e-mail: reinhard.neck@uni-klu.ac.at 
Austria, the interwar period and especially the occupation of Austria by Nazi Germany in 1938 made it impossible for them to stay in the country and exert influence there. Instead, what took place has been aptly called "the migration of a tradition" (Vaughn 1994), that is, the establishment of a small but active community of Austrian economists in the United States, led by Mises and Hayek. Nowadays there are only a few economists of Austrian School inclination left in Austria, but Austrian Economics is blossoming in the U.S., with its own scientific journals, series of books and some influence on the political discourse there. Among other institutions (such as the Liberty Fund) the Atlantic Economic Journal was instrumental in the revival of the School by devoting a special issue to it as early as 1978 (issue 3 of volume 6). The present special issue aims at continuing this tradition by gathering several contributions by Austrian economists from both sides of the Atlantic.

Earlier versions of four papers (by Bögenhold, Klausinger, Luther, and Stringham) were presented at the IAES Conference in Vienna, April 2013. They are joined here by four other papers from Austrian economists who were invited to contribute to this special issue. The Presidential Address delivered by the present author at the Vienna and the Philadelphia IAES Conferences was also devoted to the Austrian School; it will be published in the September issue of the AEJ. These papers provide examples of work done by Austrian economists and show some of the topics on which they focus. They include analyses of institutions (Peter J. Boettke and Rosolino Candela on the law as a factor of production), growth theory (G.P. Manish and Benjamin Powell on the implications of the Austrian theory of capital), macroeconomic theory (Steven Horwitz on the Austrian analysis of deflation) and empirics (William J. Luther and Mark Cohen on tests of propositions from Austrian business cycle theory), and application of the Austrian analysis of markets to the emergence of (traditionally public) rules and regulations (Edward P. Stringham) and the global arms markets (Christopher J. Coyne and Abigail R. Hall). The final two contributions shed light on the role of Anti-Semitism in the decline of Austrian economics after World War I (Hansjoerg Klausinger) and on the position and present importance of Joseph A. Schumpeter, an economist trained in the spirit and by members of the Austrian School who later developed an independent approach aiming at a universal social science (Dieter Bögenhold). We hope that this special issue, in addition to contributing to the interAustrian scientific debate, will raise interest in the ideas of the Austrian School of Economics among economists not belonging to the School and induce them to consider arguments developed by its proponents and fellow researchers.

\section{References}

Menger, Carl. (1871). Grundsätze der Volkswirthschaftslehre, Vol. 1, Vienna: Wilhelm Braumüller. Translated as Principles of Economics by James Dingwall and Bert F. Hoselitz, New York: New York University Press.

Carl Menger and Austrian Economics. (1978). Atlantic Economic Journal, Vol. 6, Issue 3. Edwardsville, IL: Atlantic Economic Society.

Vaughn, K. I. (1994). Austrian Economics in America. The Migration of a Tradition. Cambridge: Cambridge University Press. 